\title{
Acute Appendicitis Caused by Enterobius Vermicularis: Case Report
}

\section{Enterobius Vermicularis'in Neden Olduğu Akut Apandisit: Olgu Sunumu}

\section{(i) Murat ABA ${ }^{1}$, id Ahmet Onur DEMIREL 1 , id Ahmet Gökhan SARITAŞ11, id Büşranur ATEŞ2}

${ }^{1}$ Çukurova University Faculty of Medicine, Department of General Surgery, Adana, Turkey

${ }^{2}$ Çukurova University Faculty of Medicine, Department of Patology, Adana, Turkey

\section{ABSTRACT}

Enterobius vermicularis is one of the most common bowel parasites worldwide. It can be located in the lumen of the ceacum and appendix and rarely causes acute appendicitis disease. In this case, we present a 36 years old female patient who underwent appendectomy with the preliminary diagnosis of acute appendicitis. Enterobius vermicularis was detected by histopathological examination.

Keywords: Apppendectomy, acute appendicitis, Enterobius vermicularis

\section{ÖZ}

Enterobius vermicularis tüm dünyada en sık görülen barsak parazitlerindendir. Çekum ve apendiks lümeninde yerleşim göstererek nadir de olsa akut apandisit tablosuna sebep olabilmektedir. Bu olguda akut apandisit ön tanısıyla apendektomi uygulanan ve histopatolojik incelemesinde Enterobius vermicularis saptanan 36 yaşında kadın hasta sunulmaktadır.

Anahtar Sözcükler: Apendektomi, akut apandisit, Enterobius vermicularis

\section{Introduction}

Acute appendicitis (AA) is the most common cause of acute abdomen requiring surgical treatment (1). Appendectomy is one of the most common surgeries performed in general surgery practice, and the indication is often AA (2). While the lifetime probability of getting the diagnosis of AA is $8.6 \%$ in men and $6.7 \%$ in women, this probability is $12 \%$ in men and $25 \%$ in women for undergoing appendectomy (3). AA often occurs as a result of obstruction of the lumen of the appendix due to fecalitis or lymphoid tissue hypertrophy; however, parasitic infestations such as Enterobius vermicularis may rarely cause AA (4). Enterobius vermicularis is known as the most common helminthic infestation among gastrointestinal infections worldwide (5). The relationship between Enterobius vermicularis infestation and appendicitis was first described in 1899 (6). In our patient, we aimed to present the Enterobius vermicularis infestation in a 36-year-old female patient who was operated with a pre-diagnosis of AA.

\section{Case Report}

A 36-year-old female patient presented to the emergency department with complaints of abdominal pain, nausea and loss of appetite for the last two days. On physical examination, there was defense, rebound and tenderness in the right lower quadrant of her abdomen. In laboratory tests; white blood cell count was $11,80010^{3} / \mathrm{mL}$, hemoglobin level was $14.5 \mathrm{~g} / \mathrm{dL}$, hematocrit was $41.9 \%$, and other biochemical parameters were evaluated in the normal range. Appendix could not be visualized in ultrasonography. In abdominal computed tomography, it was 
evaluated that there was a blunt-ending tubular structure with an increased wall thickness and an inflamed appearance in the right paracecal region, which was separating from the cecum and extending to the subhepatic area (findings compatible with AA) (Figure 1).

A laparoscopic appendectomy decision was made for the patient. Consent was obtained from the patient for the operation. In the intraoperative exploration, it was observed that the wall thickness increased at the level of the cecum. The appendix with extensive mesenteric inflammation and serous free fluid around it and with increased wall thickness, extending retrocecally to the subhepatic area, was detected. Laparoscopic appendectomy was performed. There were no intraoperative complications. On the first postoperative day, oral regimen was started after the passing of gas and stool, and the patient could tolerate the oral regimen.

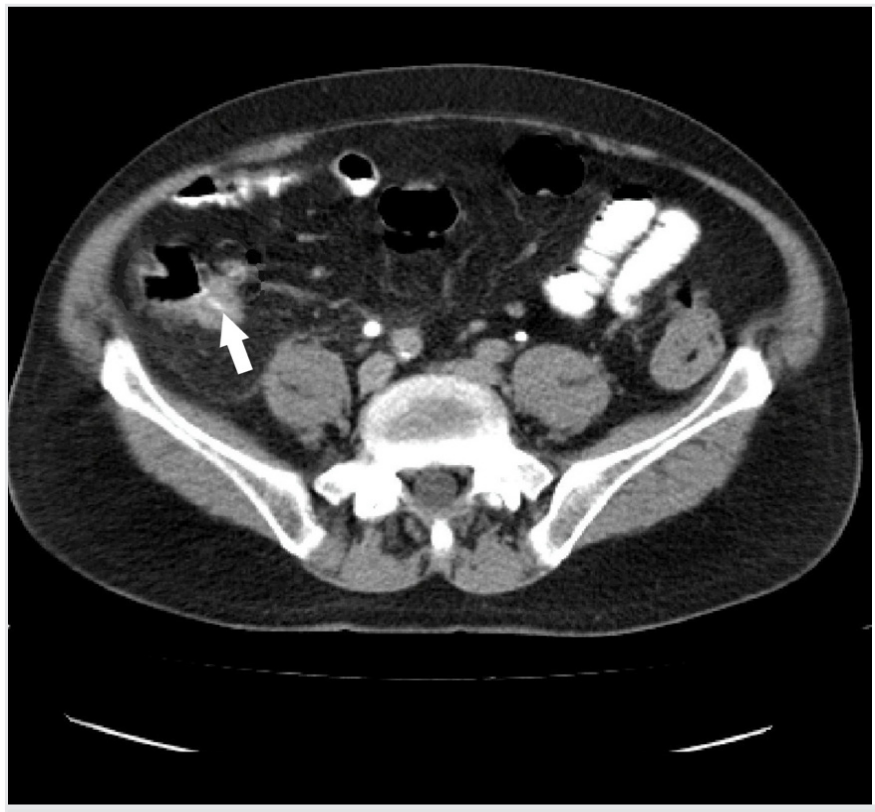

Figure 1. Computed tomography image of the appendix

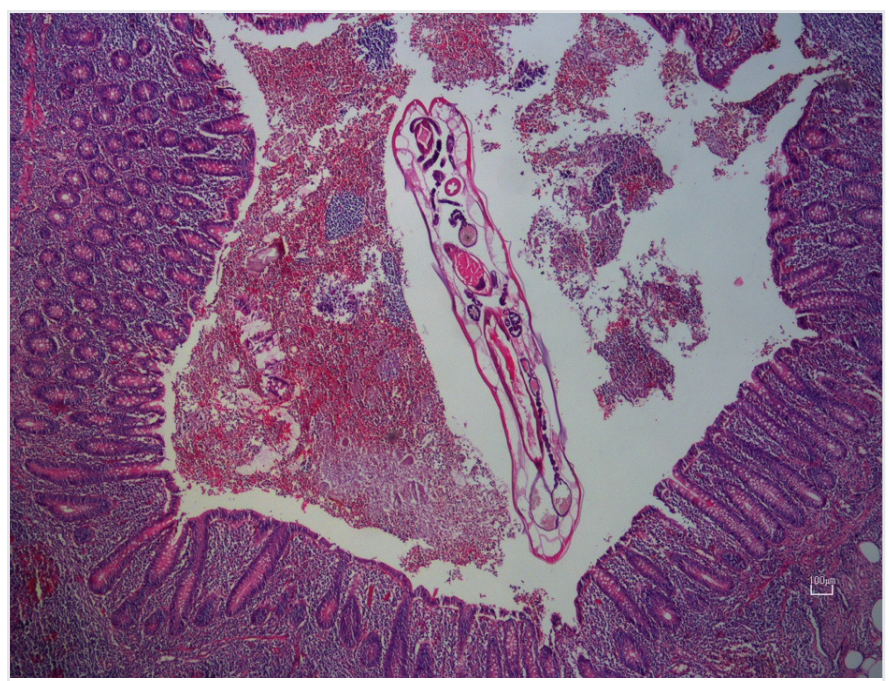

Figure 2. Image of Enterobius Vermicularis in the lumen of the appendix
The patient was discharged on the third postoperative day. Postoperative pathology specimen was found to have Enterobius vermicularis in the lumen of the appendix, and findings compatible with AA were found (Figure 2). The patient and her family relatives were referred to the clinic of infectious diseases for anthelmintic treatment.

\section{Discussion}

AA is one of the most common causes of emergency surgery today (7). The gold standard method in its treatment is appendectomy. Although Enterobius vermicularis infestation is seen in all age groups, its prevalence is higher in childhood (8). Its spread in humans is most common through the fecal-oral route (9). The most common locations of the infestation are appendix and cecum lumen (10). It is more common in women than in men (11). The overall incidence of Enterobius vermicularis in patients with AA is between $0.2 \%$ and $4 \%$ (12). It is generally thought to cause mechanical obstruction in the lumen or cause a colic condition secondary to hypersensitivity (13).

It should be kept in mind that Enterobius vermicularis infestation may be present in the patient's history in the preoperative period. A careful pathological examination to be made in the post-operative period will have important contributions to the treatment process of the patient and his/her relatives.

Anthelmintic treatment and laboratory examinations should be performed in all family members in a patient with Enterobius vermicularis infestation, because there is a risk of transmission among the family members of the patient.

Enterobius vermicularis is a rare cause in the etiopathogenesis of $\mathrm{AA}$, and antiparasitic treatment should be planned for the patients and their relatives living in the same house, who have positive parasitic examinations in the postoperative period.

Informed Consent: Obtained.

Peer-review: Externally peer reviewed.

\section{Authorship Contributions}

Concept: M.A., A.O.D., A.G.S., B.A., Design: M.A., A.O.D., A.G.S., B.A., Data Collection or Processing: M.A., A.O.D., A.G.S., B.A., Analysis or Interpretation: M.A., A.O.D., A.G.S., B.A., Literature Search: M.A., A.O.D., A.G.S., B.A., Writing: M.A., A.O.D., A.G.S., B.A.

Conflict of Interest: No conflict of interest was declared by the authors.

Financial Disclosure: The authors declared that this study received no financial support.

\section{References}

1. Humes DJ, Simpson J. Acute appendicitis. BMJ 2006;333:530-4.

2. Yabanoglu H, Caliskan K, Ozgur Aytac H, Turk E, Karagulle E, Kayaselcuk F, et al. Unusual findings in appendectomy specimens of adults: retrospective analyses of 1466 patients and a review of literature. Iran Red Crescent Med J 2014;16:12931. 
3. Flum DR, Koepsell T. The clinical and economic correlates of misdiagnosed appendicitis: nationwide analysis. Arch Surg 2002; 137:799-804.

4. Dorfman S, Cardozo J, Dorfman D, Del Villar A. The role of parasites in acute appendicitis of pediatric patients. Invest Clin 2003;44:33740.

5. Karatepe O, Adas G, Tukenmez M, Battal M, Altiok M, Karahan S. Parasitic infestation as cause of acute appendicitis. G Chir 2009;30:426-8.

6. Ahmed MU, Bilal M, Anis K, Khan AM, Fatima K, Ahmed I, et al. The Frequency of Enterobius Vermicularis Infections in Patients Diagnosed With Acute Appendicitis in Pakistan. Glob J Health Sci 2015;7:196-201.

7. Jones PF. Suspected acute appendicitis: trends in management over 30 years. Br J Surg 2001;88:1570-7.

8. Türkcü G, Keleş A, Alabalık U, Soylu B, İbiloglu İ, Dursun FS, ve ark. 1829 apendektomi materyalinin retrospektif olarak değerlendirilmesi. Harran Üniversitesi Tip Fakültesi Dergisi 2015;12:193-9.
9. Goldman DA, Wilson CM. Pinworm infestations. Primary pediatric care 3. Edition. Hoekelman RA. St Louis: Mosby. 1997;1519.

10. Gatti S, Lopes R, Cevini C, Ijaoba B, Bruno A, Bernuzzi AM, et al. Intestinal parasitic infections in an institution for the mentally retarded. Ann Trop Med Parasitol 2000;94:453-60.

11. Kurt A, Çalık İ, Ömeroğulları Şener E, Akalp Özmen S, Gelincik İ. Apendektomi materyallerinde E. vermicularis. Van Tip Dergisi 2012;19:51-4.

12. Dahlstrom JE, Macarthur EB. Enterobius vermicularis: a possible cause of symptoms resembling appendicitis. Aust $N$ Z J Surg 1994;64:692-4.

13. Akkapulu N, Abdullazade S. Is Enterobius vermicularis infestation associated with acute appendicitis? Eur J Trauma Emerg Surg 2016;42:465-70. 